\title{
Deiodinase Deficiency
}

National Cancer Institute

\section{Source}

National Cancer Institute. Deiodinase Deficiency. NCI Thesaurus. Code C131435.

Presumed loss-of-function mutation(s) in the IYD gene, resulting in reduced activity of the enzyme iodotyrosine deiodinase. 